\title{
Economic mineralization in pegmatites: comparing and contrasting NYF and LCT examples
}

\author{
Kathryn M Goodenough ${ }^{1}$, Richard A Shaw ${ }^{2}$, Martin Smith ${ }^{3}$, Guillaume Estrade ${ }^{4}$, Eva Marquis ${ }^{3}$, Cyrielle \\ Bernard 4 \& Paul Nex 5 . \\ ${ }^{1}$ British Geological Survey, Edinburgh, UK, kmgo@bgs.ac.uk \\ ${ }^{2}$ British Geological Survey, Keyworth, Nottingham, UK \\ ${ }^{3}$ School of Environment and Technology, University of Brighton, UK \\ ${ }^{4}$ Geosciences Environnement Toulouse, France \\ ${ }^{5}$ University of the Witwatersrand, South Africa
}

Keywords: pegmatite, resources, critical metals

\section{Introduction}

Granitic pegmatites can represent superb deposits of rare metals, including some 'critical metals' that are important for many modern technologies (Linnen et al., 2012; London, 2018). Notably, the majority of ore deposits associated with granitic pegmatites are found in LCT pegmatites, which represent many of the world's resources of lithium, tantalum, caesium and beryllium. In contrast, the NYF pegmatites may be enriched in the rare earth elements (REE) and niobium, but they rarely contain economic resources of these metals. Compared with LCT pegmatites, NYF pegmatites have seen relatively little research. This contribution will compare recent work from examples of the two pegmatite families and summarise how magmatic and hydrothermal processes affect their potential as ore deposits.

\section{NYF pegmatites}

The NYF family of pegmatites is characterized by enrichment in $\mathrm{Nb}, \mathrm{Ti}, \mathrm{Y}$, rare earth elements (REE), $\mathrm{Zr}$, U, Th and $\mathrm{F}$ and considered to be typically associated with metaluminous to alkaline (locally peralkaline) granitic bodies (Černý and Ercit, 2005). Classic examples of NYF pegmatites (and aplites) associated with peralkaline granites occur at Khan Bogd in Mongolia (Kynicky et al., 2011); Strange Lake in Canada (Vasyukova and Williams-Jones, 2014); and the Amis Complex in Namibia (Schmitt et al., 2002). In all cases, the pegmatites are within the roof zone of, or very close to, the larger granitic intrusion. These pegmatites are generally considered to represent the most evolved magmas within the granitic body, and are particularly enriched in $\mathrm{Nb}, \mathrm{Zr}$ and the REE, most commonly hosted in zirconosilicate minerals such as elpidite. In these settings, the pegmatites most commonly show evidence of alteration by a latestage, typically $\mathrm{F}$ - and $\mathrm{CO}_{2}$-rich fluid, considered to have formed by immiscibility within the magma chamber. Some authors suggest that rather than fluids, immiscible silicate and fluoride melts were produced, and subsequently crystallised to form the pegmatites (Vasyukova and Williams-Jones, 2014).

As part of the SoS RARE project (www.sosrare.org) we have been working on NYF pegmatites with a particular focus on the Cenozoic alkaline province of the Ampasindava Peninsula in Madagascar, particularly the Ambohimirahavavy and Manongarivo intrusive complexes. These are large $(>10 \mathrm{~km}$ across) alkaline to peralkaline ring complexes in which the dominant intrusive rock-types are syenites and nepheline syenites. The parental magmas for these complexes are considered to have been largely mantlederived, with extensive magmatic evolution occurring through fractional crystallization and local crustal contamination (Cucciniello et al., 2016). Both complexes contain late-stage peralkaline granite and pegmatite sheets; in Ambohimirahavavy these intrude the country rocks at the margin of the complex (Estrade et al., 2014a) whilst at Manongarivo they cut the host syenites. These intrusions formed by crustal 
contamination of highly evolved melts within the syenitic complexes (Estrade et al., 2014b). The granitic pegmatites are typically $<1 \mathrm{~m}$ in thickness, with a banded aplitic-pegmatitic appearance. These granitic pegmatites are relatively enriched in the REE and $\mathrm{Nb}$, but their mineralogy is extremely complex. Rare examples contain an agpaitic mineral assemblage with eudialyte, but the majority of the pegmatites show evidence of extensive alteration of primary magmatic minerals by an alkaline hydrothermal fluid (Estrade et al., 2014a). Detailed mineralogical analysis indicates that, during evolution of the granitic magma, exsolution of a late-stage highly saline fluid occurred and mobilised many of the rare metals, which were then deposited into skarn and veinlet mineralization rather than being trapped within the pegmatite bodies. This has led to mineralisation being widely disseminated, with the REE enriched in a range of minerals, not all of which are amenable to processing and REE extraction. The pegmatites themselves are thus not considered to represent potential economic resources, but the Ambohimirahavavy complex has been explored for REE adsorbed onto clays in the weathered zone of the deposit. The extensive hydrothermal alteration means that a substantial proportion of bedrock REE were contained within secondary minerals that were relatively susceptible to weathering.

\section{LCT pegmatites}

In contrast to NYF pegmatites, LCT pegmatites are characterised by enrichment in $\mathrm{Li}, \mathrm{Cs}, \mathrm{Rb}, \mathrm{Be}$ and $\mathrm{Ta}$, and are considered to be associated with peraluminous granitic bodies formed by melting of (meta)sedimentary crustal material (Černý and Ercit, 2005). Unlike the NYF pegmatites described above, LCT pegmatites are not always found within or very close to their parent granitic plutons, and in some cases there is no evidence of a parental granite at all. We have recently studied examples of LCT-type pegmatites with no parental granite at South Harris in Scotland (Shaw et al., 2016) and at Kamativi in Zimbabwe (Shaw et al., this conference). LCT pegmatites can be very large in size (e.g Greenbushes, Australia, up to hundreds of metres in thickness; Partington et al., 1995) and represent major global resources of Li, Cs and Ta (Linnen et al., 2012; London, 2018).

Although LCT pegmatites can have very complex mineralogy, the majority of economic Li mineralisation has spodumene and petalite as the ore minerals, and these are generally considered to be primary magmatic in origin (London, 2018). However, as with the NYF pegmatites in Madagascar, there is extensive evidence for the importance of late-stage fluid immiscibility and alteration, which may significantly affect ore mineral assemblages (Thomas and Davidson, 2016). At Kamativi, for example, primary spodumene-bearing assemblages are extensively replaced by quartz-albite-muscovite assemblages which indicate late-stage hydrothermal alteration and remobilisation of the critical metals by fluids or very volatile-rich melts. In contrast to the NYF pegmatites in Madagascar, this late-stage alteration appears to have been largely positive for the formation of ore deposits at Kamativi, in particular allowing concentration of $\mathrm{Sn}$ and $\mathrm{Ta}$ within the pegmatite, although breakdown of spodumene has potentially affected $\mathrm{Li}$ prospectivity. In South Harris, there is similar evidence that albitisation has been associated with the concentration of Ta in certain pegmatites. Notably, at South Harris, the pegmatites were emplaced during a crustal thickening event that occurred $>100 \mathrm{Ma}$ after the peak of metamorphism in their country rocks, suggesting that an influx of external fluid was an important driver for anatexis (Shaw et al., 2016).

\section{Summary}

Study of both peralkaline NYF and peraluminous LCT rare-metal pegmatites highlights the importance of key processes that significantly impact critical-metal prospectivity. The two pegmatite types discussed here form from very different sources, with the NYF pegmatites derived by evolution of a mantle-derived magma, and the LCT pegmatites formed by melting of (meta)sedimentary crust. Peralkaline NYF pegmatites in Madagascar are relatively small in scale, and associated with syenitic ring complexes. LCT pegmatites in Scotland and Zimbabwe are rather larger in scale, and emplaced into metasedimentary inliers within cratons, but are not demonstrably associated with parental granites. Both types of pegmatite were formed from highly evolved volatile-rich melts, from which a highly saline fluid (or melt) eventually exsolved and altered the magmatic mineral assemblages, remobilising the critical metals. Such alteration 


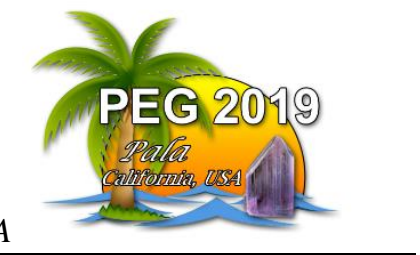

can have both positive and negative impacts on critical metal prospectivity, since it may concentrate the metals of interest, but may also lead to replacement of processable magmatic minerals by complex intergrowths that are less amenable to processing. In the NYF pegmatites, these late fluids are considered to be entirely magmatic in origin; however, in the LCT fluids, a component of externally-derived fluid may have been important for crustal anatexis and pegmatite formation.

\section{Acknowledgements}

The work described here draws on research funded by the European Commission through the HiTech AlkCarb (H2020 grant 689909) project, and by NERC through SoS RARE (NE/M01116X/1) and the Geoscience for Sustainable Futures ODA programme at BGS.

\section{References}

Černý, P. and Ercit, T.S. (2005): The classification of Granitic Pegmatites revisited. Canadian Mineralogist 43, pp. 2005-2026.

Cucciniello, C., Tucker, R.D., Jourdan, F., Melluso, L. and Morra, V. (2016): The age and petrogenesis of alkaline magmatism in the Ampasindava Peninsula and Nosy Be archipelago, northern Madagascar. Mineralogy and Petrology 110, 309-331.

Estrade, G, Salvi, S., Béziat, D., Rakotovao, S., and Rakotondrazafy (2014a): REE and HFSE mineralization in peralkaline granites of the Ambohimirahavavy alkaline complex, Ampasindava peninsula, Madagascar. Journal of African Earth Sciences 94, 141-155

Estrade, G., Béziat, D., Salvi, S., Tiepolo, M., Paquette, J-L., and Rakotovao, S. (2014b): Unusual evolution of silica under- and oversaturated alkaline rocks in the Cenozoic Ambohimirahavavy Complex (Madagascar): mineralogical and geochemical evidence. Lithos 206-207, 361-383.

Kynicky, J., Chakhmouradian, A.R., Xu, C., Krmicek, L. and Galiova, M. (2011): Distribution and evolution of zirconium mineralisation in peralkaline granites and associated pegmatites of the Khan Bogd complex, Southern Mongolia. Canadian Mineralogist 49, pp 947-965

Linnen, R.L., Van Lichtervelde, M., and Černý, P. (2012): Granitic Pegmatites as Sources of Strategic Metals. Elements, 8, pp 275-280

London, D. (2008): Pegmatites. Canadian Mineralogist, Special Publication, 10, 347 pp.

London, D. (2018): Ore-forming processes within granitic pegmatites. Ore Geology Reviews, 101, 349-383

Partington, G.A. (1995): A Review of the Geology, Mineralization, and Geochronology of the Greenbushes Pegmatite, Western Australia Economic Geology 90, 616-635

Schmitt, A.K., Trumbull, R.B., Dulski, P., and Emmermann, R. (2002). Zr-Nb-REE Mineralization in Peralkaline Granites from the Amis Complex, Brandberg (Namibia): Evidence for Magmatic Preenrichment from Melt Inclusions. Economic Geology, 97, 399-413

Thomas, R. and Davidson, P. (2016): Revisiting complete miscibility between silicate melts and hydrous fluids, and the extreme enrichment of some elements in the supercritical state - consequences for the formation of pegmatites and ore deposits. Ore Geology Reviews 72, 1088-1101

Vasyukova, O. and Williams-Jones, A.E. (2014): Fluoride-silicate melt immiscibility and its role in REE ore formation: Evidence from the Strange Lake rare metal deposit, Québec-Labrador, Canada. Geochemica et Cosmochimica Acta 139, 110-130 
Please indicate your preferred presentation type.

$\otimes$ Oral presentation

$\square$ Poster presentation 